University of Nebraska - Lincoln

DigitalCommons@University of Nebraska - Lincoln

\title{
Use of Partially Fenced Fields to Reduce Deer Damage to Corn
}

Aaron M. Hildreth

University of Nebraska-Lincoln, hildreta@gmail.com

Scott E. Hygnstrom

University of Nebraska-Lincoln, shygnstrom1@unl.edu

Erin E. Blankenship

University of Nebraska-Lincoln, erin.blankenship@unl.edu

Kurt C. VerCauteren

National Wildlife Research Center, kurt.c.vercauteren@usda.gov

Follow this and additional works at: https://digitalcommons.unl.edu/natrespapers

Part of the Natural Resources and Conservation Commons, Natural Resources Management and Policy Commons, and the Other Environmental Sciences Commons

Hildreth, Aaron M.; Hygnstrom, Scott E.; Blankenship, Erin E.; and VerCauteren, Kurt C., "Use of Partially Fenced Fields to Reduce Deer Damage to Corn" (2012). Papers in Natural Resources. 367.

https://digitalcommons.unl.edu/natrespapers/367

This Article is brought to you for free and open access by the Natural Resources, School of at DigitalCommons@University of Nebraska - Lincoln. It has been accepted for inclusion in Papers in Natural Resources by an authorized administrator of DigitalCommons@University of Nebraska - Lincoln. 


\title{
Use of Partially Fenced Fields to Reduce Deer Damage to Corn
}

\author{
AARON M. HILDRETH, ${ }^{\mathbf{1 , 2}}$ School of Natural Resources, University of Nebraska-Lincoln, 3310 Holdrege Street, Lincoln, NE 68583, USA \\ SCOTT E. HYGNSTROM, School of Natural Resources, University of Nebraska-Lincoln, 3310 Holdrege Street, Lincoln, NE 68583, USA \\ ERIN E. BLANKENSHIP, Department of Statistics, University of Nebraska-Lincoln, 3310 Holdrege Street, Lincoln, NE 68583, USA \\ KURT C. VerCAUTEREN, United States Department of Agriculture, Animal and Plant Health Inspection Service, Wildlife Services, \\ National Wildife Research Center, 4101 LaPorte Avenue, Fort Collins, CO 80521, USA
}

\begin{abstract}
White-tailed deer (Odocoileus virginianus) damage agricultural crops, often leading to significant economic losses for farmers. We used poly-mesh fence with wings to separate good deer cover from agricultural fields where crop damage by deer occurred primarily along this edge. In these cases, complete enclosure of the field with fencing may be unnecessary. The design used a 2.13-m-high polypropylene mesh fence erected along the wooded edge of a field with either 50-m or 150-m wings extending perpendicular from the fence line and wooded habitat. Fences reduced deer damage in cornfields $13.5 \%\left(F_{1,6}=\infty\right.$, $P<0.001)$. Average yield in fenced fields $(10,211 \mathrm{~kg} / \mathrm{ha})$ was $1,708 \mathrm{~kg} / \mathrm{ha}$ greater than in control fields, which, at US $\$ 0.155 / \mathrm{kg}$, equals a net gain of US $\$ 265 / \mathrm{ha}$. We found no difference in damage between fences with $50-\mathrm{m}$ and $150-\mathrm{m}$ wings $\left(F_{1,1}=0.26, P=0.695\right)$. Costs for materials and labor for erecting partial poly-mesh fences with wings were US $\$ 5.56 / \mathrm{m}$ and US $\$ 1.42 / \mathrm{m}$, respectively. Mean total cost for partial poly-mesh fences with $50-\mathrm{m}$ wings would be US $\$ 60.13 / \mathrm{ha} /$ year over a 10 -year period, compared with US $\$ 82.30 / \mathrm{ha} /$ year for 150 -m wings and US $\$ 184.16 / \mathrm{ha} /$ year for completely enclosing fields. Expected savings for partial poly-mesh fences with 50 -m wings over a 10 -year period were US $\$ 205 /$ ha/year, as compared with damaged fields without fences. We concluded that poly-mesh fences with $50-\mathrm{m}$ wings were cost-effective at reducing damage by deer to corn. Additional research should be conducted to determine efficacy of the more cost-effective high-tensile and poly-tape fences with wings. (C) 2012 The Wildlife Society.
\end{abstract}

KEY WORDS corn, damage, fence, Odocoileus virginianus, polypropylene mesh, white-tailed deer, wildlife damage management.

Populations of white-tailed deer (Odocoileus virginianus) have increased across the United States in recent years (Côté et al. 2004). Damage to crops has increased along with the increase in densities of deer (Smathers et al. 1993, $\mathrm{McNew}$ and Curtis 1997). Farmers often accept about 10\% damage to crops from wildlife (Craven et al. 1992, Craven and Hygnstrom 1994), and many seek ways to reduce damage when it exceeds acceptable levels. State wildlife agencies historically have used a variety of methods, including depredation permits, crop-loss payments, and fencing entire fields to help farmers reduce damage to crops. The crop being grown and size of field are primary determinants in benefit:cost ratios associated with control methods that are available to farmers (VerCauteren et al. 2006b). High-value crops (e.g., ornamentals, nursery, fruit) provide greater justification and allow for more expensive and effective control methods compared with relatively low-value agricultural crops (e.g.,

Received: 13 June 2011; Accepted: 30 December 2011;

Published: 2 March 2012

\footnotetext{
${ }^{1}$ E-mail: hildreta@gmail.com

${ }^{2}$ Present address: Department of Forestry, University of Kentucky, 218

T. P. Cooper Building, Lexington, KY 40546, USA.
}

corn, soybeans, wheat). Cost per unit area decreases as the protected area increases (VerCauteren et al. 2006b). Fences are valuable tools for reducing crop damage by deer, but fence designs and materials vary greatly, as do costs and effectiveness. Two-strand poly-tape fences cost $<\mathrm{US} \$ 2.00 / \mathrm{m}$ to install and are $60-70 \%$ effective at reducing deer damage, while $2.4-\mathrm{m}$ polypropylene mesh (poly-mesh) fences cost up to US $\$ 20.00 / \mathrm{m}$ and reduce damage $90-99 \%$ (VerCauteren et al. 2006a,b). The ability to maximize cost-effectiveness is crucial to the success of using fences for agricultural crop protection.

Home ranges of white-tailed deer typically consist of 51-80\% wooded habitat, but white-tailed deer repeatedly venture out into crop fields for food (VerCauteren and Hygnstrom 1998). Fences used for reducing crop damage by deer typically surround entire fields to inhibit access to deer from all directions. Deer use and damage, however, often does not come from all directions and fences may not have to completely surround fields to be effective at reducing deer damage. Damage to corn and soybeans from deer is most likely to occur around wooded habitat (DeVault et al. 2007). Retamosa et al. (2008) found that the rate of crop damage was positively related to the amount of the field's 
perimeter adjacent to wooded habitat. Fences along edges of wooded habitat and not around entire fields may reduce deer damage and the amount of fencing required to reduce damage to tolerable levels. Thus, the cost-effectiveness of deer fencing may be increased because complete exclusion may be unnecessary when using partial fences with wings that extend out from forested habitats. To our knowledge, no other researchers have designed or tested partial fences with wings.

Deer activity in cornfields in Nebraska, USA typically peaks during the silking-tasseling stage (Hygnstrom et al. 1992), when corn is reported to be highly susceptible to deer damage (Eldredge 1935, Shapiro et al. 1986, Vorst 1986, Hygnstrom et al. 1992). The potential yield of the corn plant is greatly reduced when the young ears of corn are eaten by deer, and remaining ears are often of lower quality. Fences installed prior to this critical stage of development likely will reduce yield loss to deer damage.

Deer in Nebraska occasionally damage corn fields and reduce yields by $\geq 50 \%$, depending on field size and location. Some of the most problematic areas are along major river valleys, including along the Missouri and Elkhorn rivers. The Nebraska Game and Parks Commission's desired density of deer in these areas is $12 \mathrm{deer} / \mathrm{km}^{2}$. As densities increase above 12 deer $/ \mathrm{km}^{2}$, damage reports and problems increase.

We developed and tested 4 temporary, partial, poly-mesh fences with wings to determine whether $50-\mathrm{m}$ and $150-\mathrm{m}$ wings would be effective at reducing deer damage to cornfields. We predicted that fields protected with partial poly-mesh fences with wings would sustain less damage by white-tailed deer than would unprotected control fields and that damage would be less in fields protected with $150-\mathrm{m}$ wings than in those with 50 -m wings.

\section{STUDY AREA}

We conducted our research in the Missouri River Valley in eastern Nebraska and western Iowa, USA. We concentrated efforts in and around the 3,384-ha DeSoto National Wildlife Refuge (DNWR) and along the Missouri River and Elkhorn River, northwest of Omaha, Nebraska. More than half of the landcover consisted of agricultural crops, including corn, soybeans, and winter wheat. The remaining landcover consisted of eastern deciduous forest, which was dominated by mature eastern cottonwood (Populus deltoides). Understory included rough-leafed dogwood (Cornus drummondii), hackberry (Celtis occidentalis), mulberry (Morus rubra), and green ash (Fraxinus pennsylvanica). Poison ivy (Toxicodendron radicans) and common scouring-rush (Equisetum hyemale) dominated the ground layer. Native grasses included big bluestem (Andropogon gerardii), little bluestem (Schizachyrium scoparium), indiangrass (Sorghastrum nutans), switchgrass (Panicum virgatum), and sideoats grama (Bouteloua curtipendula). Total precipitation in 2009 was $894 \mathrm{~mm}$ compared with the mean annual precipitation of $736 \mathrm{~mm}$, with mean annual minimum and maximum temperatures of $5.3^{\circ} \mathrm{C}$ and $15.5^{\circ} \mathrm{C}$, respectively (Pearce and Smith 1990). We estimated that the density of white-tailed deer at DNWR during winter 2009-2010 was $28 \mathrm{deer} / \mathrm{km}^{2}$ (G. Clements,
University of Nebraska-Lincoln, unpublished data). The Nebraska Game and Parks Commission manages for approximately $12 \mathrm{deer} / \mathrm{km}^{2}$ in eastern Nebraska and along the Missouri River. One of the criteria they use in determining whether or not to issue depredation permits is a deer density above $12 \mathrm{deer} / \mathrm{km}^{2}$. All of the sites used had a prior history of deer densities above this level and current sign of deer activity.

\section{METHODS}

We used 4 pairs of cornfields of similar size, situation, and location for comparing the effects of treatments and controls. The average size of treatment and control fields was 9.7 ha $($ range $=5.4-12.3 \mathrm{ha})$ and $13.8 \mathrm{ha}($ range $=7.8-25.7 \mathrm{ha})$, respectively. The average distance between treatment and control fields was $0.7 \mathrm{~km}$ (range $=0.5-1.4 \mathrm{~km})$. We maintained a distance of $\geq 0.5 \mathrm{~km}$ between fields to minimize dependence of deer damage estimates among fields (Gilsdorf et al. 2004b). All fields were bordered by wooded habitat on one side; remaining sides were bordered by soybeans, pasture, native tallgrass prairie, or a pond. We selected sites within areas of high densities of white-tailed deer $\left(>12 \mathrm{deer} / \mathrm{km}^{2}\right)$, near riparian habitat used extensively by deer, and where depredation permits repeatedly had been issued due to high levels of crop damage by deer.

We erected poly-mesh fences along the sides of 4 cornfields in the study area that were adjacent to wooded habitat and high densities of deer. We installed 3-m steel t-posts every $7 \mathrm{~m}$ along the fence line and used $10.16-\mathrm{cm} \times 10.16-\mathrm{cm}$ wooden posts in $\mathrm{h}$-brace assemblies at the corners and ends in treatment fields. We stretched 2 strands of 12.5 -gauge (2.5$\mathrm{mm}$ ) high-tensile wire at $0.76 \mathrm{~m}$ and $2.13 \mathrm{~m}$ above ground for the length of the fence to provide support for 2.13-m-tall poly-mesh deer netting (Benner's Gardens, Phoenixville, PA). The netting consisted of UV-stable black polypropylene with a high-strength mesh $(4.44-\mathrm{cm} \times 4.44-\mathrm{cm}$; Lavelle et al. 2010). We secured the poly-mesh to t-posts with cable ties and to high-tensile wire with hog rings every $2 \mathrm{~m}$. The fence had a $0.16-\mathrm{m}$ apron extending outward at ground level that we secured to the ground with $0.3-\mathrm{m}$ galvanized steel stakes to reduce the probability of deer breaching under the fence. At the 2 end posts of each fence, we extended the fence perpendicular to the fence line and wooded habitat into the field. These "wings" were $50 \mathrm{~m}$ long for 2 treatment fences and $150 \mathrm{~m}$ long for the other 2 treatment fences. The surrounding wooded habitat and crop fields were similar for control and treatment fields, except that no fences were installed. We randomly assigned treatments to each of the pairs. All fences were constructed in early June 2009 when the corn was $0.3 \mathrm{~m}$ tall, and we recorded costs of materials and labor for each of the fields.

We assessed damage to corn in treatment and control fields in early August using a variable-area-transect sampling method (Engeman and Sugihara 1998, Engeman and Sterner 2002). The location of each sampling plot was chosen within treatment and control fields at random and with replacement. We used low- and high-intensity sampling plots (LISP, HISP) to assess damage (Fig. 1). 


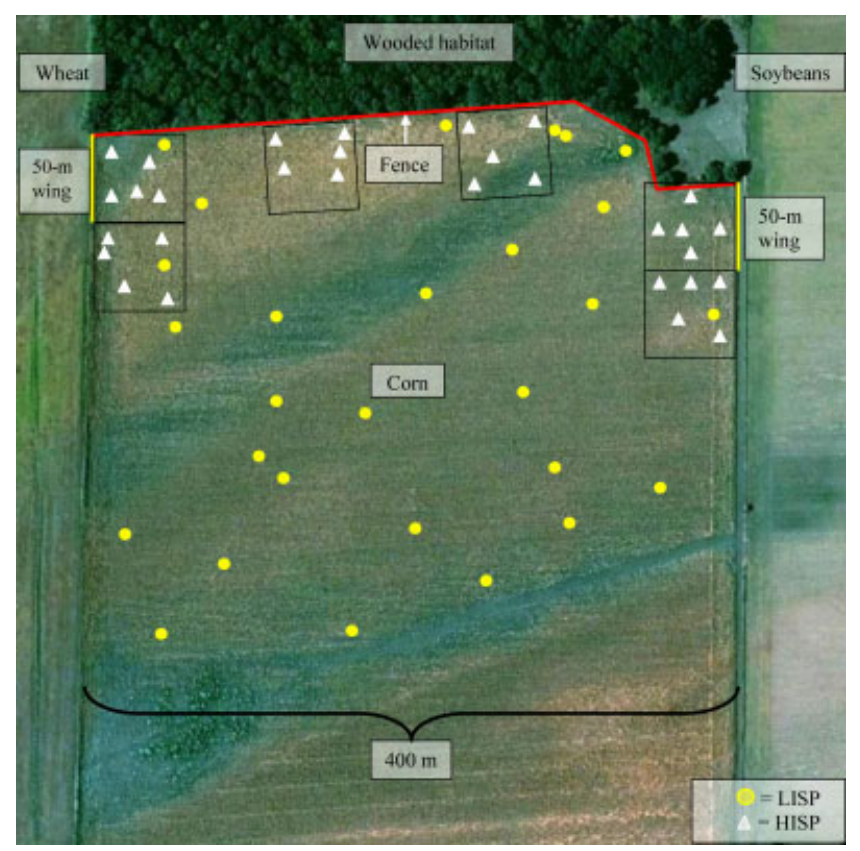

Figure 1. Diagram of partially fenced field with $50-\mathrm{m}$ wings installed perpendicular to wooded habitat to reduce deer damage to cornfields and sample low- and high-intensity sampling plots (LISP, HISP) to assess deer damage to corn in eastern Nebraska, USA, 2009.

The sampling procedures (LISP and HISP) refer to the density and distribution of the plots. We sampled 2 plots/ha of the field (range $=10-52$ ) using the LISP. We focused 5 variable-area-transects within a $50-\mathrm{m} \times 50-\mathrm{m}$ area along the wings and fenced wooded habitat using the HISP. In each of the LISP, we inspected one transect (row of corn), counting the total number of ears of corn that were damaged and undamaged by deer. We recorded length of transect and total number of ears present until 5 deer-damaged ears were tallied. If 5 deer-damaged ears were not tallied, the observer recorded the total number of ears including deer-damaged ears observed in $100 \mathrm{~m}$ of row. We calculated the percentage of ears damaged per plot using the following equation: damage per plot $=$ [damaged ears/ (damaged ears + undamaged ears) $] \times 100$ (Gilsdorf et al. $2004 a, b)$. We also randomly located 5-7 plots along the edge of field adjacent to wooded habitat for both treatment and control fields to measure damage in proximity of the highest deer pressure. We established plots at both ends of each wing and once every $200 \mathrm{~m}$ along the edge of the trees. Fences were removed after completion of the damage assessment.

We recorded plot count data and analyzed them as repeated measures. We used a randomized complete block design and analyzed the data using a mixed linear model (McLean et al. 1991) implemented in SAS Proc Mixed (Littell et al. 2006, SAS Institute Inc. 2008) with means estimated as leastsquares means. We used Akaike's Information Criterion (AIC) to select the covariance structure that provided the best-fit model for the repeated-measures analyses (Littell et al. 2006), and the Kenward-Roger adjustment for denominator degrees of freedom.

We obtained corn yields for 6 of the 8 fields from farmers who measured them with flow meters on combines while harvesting corn in October 2009. We were unable to obtain exact yields for one pair of fields with a 50-m treatment because the farmer pooled all field yields to obtain a farm yield. We estimated yield for the 2 fields based on our percentage damage estimate from each of the fields. We used data on corn yield and a 3-year average value of US $\$ 0.155 / \mathrm{kg}$ (U.S. Department of Agriculture 2011) to generate estimates of the economic effects of poly-mesh fences with $50-\mathrm{m}$ and $150-\mathrm{m}$ wings.

\section{RESULTS}

Fences encompassed an average of $40.3 \%$ (range $=32.7-$ $54.9 \%$ ) of the perimeter of the experimental fields. Crop yields from farmers, on average, were $1,708 \mathrm{~kg} / \mathrm{ha}$ or US $\$ 265 / \mathrm{ha}$ greater in fenced treatment fields $(10,211 \mathrm{~kg} / \mathrm{ha})$, including along the edge of field with no fence (59.7\%), than in unfenced control fields $(8,503 \mathrm{~kg} / \mathrm{ha})$.

The level of deer damage to corn across all treatment fields $(\bar{x}=4.4 \%, \mathrm{SE}=1.6, n=4)$ was less than in control fields $\left(\bar{x}=17.9 \%, \mathrm{SE}=7.3, n=4 ; F_{1,6}=\infty, P<0.001\right) . \mathrm{We}$ did not observe a difference between $50-\mathrm{m}$ and $150-\mathrm{m}$ wing designs in high- $\left(F_{1,1}=0.47, P=0.617\right)$ or low-intensity $\left(F_{1,1}=0.26, P=0.695\right)$ plot counts. Levels of deer damage differed between treatments and controls in HISP at the wooded edges of fields and at intensive plots (Table 1). We did not observe differences between treatment and control fields in HISP at the ends of wings and LISP distributed throughout the fields (Table 1). The best fitting model for comparison of fenced treatment and unfenced control fields, as well as $50-\mathrm{m}$ versus $150-\mathrm{m}$ treatment fields, according to AIC values were the HISP at all locations $(\mathrm{AIC}=-13.6, \mathrm{AIC}=-103.9)$. There were no relationships $(P>0.05)$ between the percent of damage $(P=0.28)$ or yield $(P=0.08)$ in treatment fields and distance to control fields.

Cost for materials and labor for installation and removal of the fences (at US $\$ 10 / \mathrm{hr}$ ) were US\$5.56/m and US $\$ 1.42 / \mathrm{m}$, respectively. Crews of 4-6 people installed fence at

Table 1. Mean levels of deer damage (\% ears damaged) in high- and low-intensity sampling plots (HISP, LISP) in systematically determined locations across cornfields protected by partial poly-mesh fences with 50-m and 150-m wings and unprotected paired control fields in eastern Nebraska, USA, 2009.

\begin{tabular}{lccccc}
\hline Plot type & $\begin{array}{c}\mathbf{5 0 - m} \text { wings } \\
\mathbf{( \% )}\end{array}$ & $\begin{array}{c}\mathbf{5 0 - m} \text { controls } \\
\mathbf{( \% )}\end{array}$ & $\begin{array}{c}\mathbf{1 5 0}-\mathbf{m} \text { wings } \\
\mathbf{( \% )}\end{array}$ & $\begin{array}{c}\text { 150-m controls } \\
\text { (\%) }\end{array}$ & $\boldsymbol{F}_{\text {- and } \boldsymbol{P} \text {-values }}^{\mathbf{a}}$ \\
\hline HISP at all locations & 4.4 & 20.1 & 5.7 & 21.4 & $F_{2,6}=34.45, P<0.001$ \\
HISP at wooded edge of fields & 4.5 & 22.2 & 4.1 & 24.6 & $F_{2,5}=21.48, P=0.003$ \\
HISP at end of wings & 4.1 & 16.1 & 9.2 & 12.9 & $F_{2,5}=1.74, P=0.274$ \\
LISP throughout fields & 5.2 & 28.8 & 3.2 & 7.4 & $F_{2,5}=1.61, P=0.288$ \\
\hline
\end{tabular}

\footnotetext{
${ }^{\text {a }}$ Values are for comparison of winged treatment fields to their paired controls.
} 
$12 \mathrm{~m} /$ hour/person. The fence required little maintenance, which consisted primarily of replacing broken cable ties.

\section{DISCUSSION}

The data supported the hypothesis that fields protected with partial poly-mesh fences with wings would sustain less damage than control fields. Fences reduced damage in cornfields by $13.5 \%$ and saved producers US $\$ 265 /$ ha.

All fenced treatment fields sustained $<10 \%$ damage (range $=0.5-7.2 \%)$. VerCauteren et al. $(2006 a, b)$ estimated the life expectancy of poly-mesh fences at 10-20 years. Averaged over an estimated life expectancy of 10 years, the cost for $250-\mathrm{m}$ wings was US $\$ 1.62 / \mathrm{m} /$ year to buy the fence, erect it, and remove it, a savings of US $\$ 205 / \mathrm{ha} /$ year compared with the cost incurred in damaged fields without fences.

The significant differences we found in levels of deer damage in treatment fields along the edge of the wooded habitat and in all intensive plot counts indicated that fences were effective at preventing deer from accessing the fenced fields at the border of wooded habitat and along the wings. We found no differences in levels of deer damage between $50-\mathrm{m}$ and $150-\mathrm{m}$ wing designs, which indicated that the $50-\mathrm{m}$ wing design was sufficient to reduce deer use of fields and cost, on average, would be US $\$ 3,950$ less than the $150-\mathrm{m}$ wing fences, and US\$22,110 less than complete exclosures, per field over 10 years (Table 2).

Although randomly assigned, treatment fields $(\bar{x}=9.7 \mathrm{ha})$ were smaller than control fields $(\bar{x}=13.8 \mathrm{ha})$, yet received noticeably less damage. Damage per unit area is thought to be greater on small fields (Gilsdorf et al. 2004a, Retamosa et al. 2008). Assuming equal deer densities surrounding both treatment and control fields, the treatment fields should have been exposed to more deer and had more damage than control fields. Fields with a greater perimeter:area ratio should receive more deer damage because a greater percentage of the crop is exposed to deer on the edges of the field (MacGowan et al. 2006, Retamosa et al. 2008).

We anticipated that the wings would direct movement of deer along the fence and lead to highly concentrated damage at the ends of the wings. However, we noticed only 2 concentrations of deer damage at the end of wings in 2 different fields. In both cases, the damage did not extend

Table 2. Estimated costs (US\$) for 2.1-m polypropylene fences installed in 17.8-ha fields to reduce deer damage in cornfields in eastern Nebraska, USA, 2009. Partial fences were installed along wooded edges of fields with 50-m and $150-\mathrm{m}$ wings extending perpendicularly into fields (as compared with hypothetical fences that would enclose entire fields).

\begin{tabular}{|c|c|c|c|c|}
\hline Fence design & $\begin{array}{c}\text { Materials } \\
(\$ / \mathrm{m})\end{array}$ & $\begin{array}{c}\text { Labor }^{a} \\
(\$ / \mathbf{m})\end{array}$ & $\begin{array}{l}\text { Materials } \\
\text { and labor } \\
(\$ / \text { ha })\end{array}$ & $\begin{array}{c}\text { Total } \\
\operatorname{cost}^{c} \\
(\$)\end{array}$ \\
\hline 50-m wing & 5.56 & 1.42 & 601.23 & 10,720 \\
\hline $150-\mathrm{m}$ wing & 5.56 & 1.42 & 822.99 & 14,672 \\
\hline Entire enclosure & 5.56 & 1.42 & $1,841.61$ & 32,831 \\
\hline
\end{tabular}

\footnotetext{
${ }^{a}$ Labor at $\$ 10 / \mathrm{hr}$.

${ }^{\mathrm{b}}$ Includes material and labor cost for $10 \mathrm{yr}$.

${ }^{\mathrm{c}}$ Includes labor cost for $10 \mathrm{yr}$.
}

$>4$ rows into the field or $>10 \mathrm{~m}$ in length. The damage observed at the ends of the wings was considerably less than that observed at locations along the wooded edge of control fields.

The partial poly-mesh fence with wings will be most effective in areas where deer use and damage is unidirectional and focused on one side of a field. All of the fields in this study had only one wooded side. Fields completely surrounded by deer habitat and high densities of deer likely would need to be fenced entirely or protected by another method of damage prevention. It is also worth noting that changes in precipitation from the annual mean may affect natural food availability and crop damage by deer.

\section{MANAGEMENT IMPLICATIONS}

All of the cornfields protected with partial poly-mesh fences with wings experienced damage below the critical damage level of $10 \%$, suggesting most farmers would be tolerant of the damage. The availability of a seasonal, cost-effective partial fence with wings that provides acceptable levels of damage will enable farmers to tolerate higher densities of deer in localized areas.

We suggest testing of additional fencing materials, such as high-tensile and poly-tape electric fences with wings to determine their effectiveness at protecting corn and other grain fields. In addition, partial fences with wings should be tested on high-value crops, including fruits and vegetables, to determine the ability of the design to deter deer and provide cost-effective management of deer damage.

\section{ACKNOWLEDGMENTS}

We thank the University of Nebraska-Lincoln School of Natural Resources and the National Wildlife Research Center of the U.S. Department of Agriculture (USDA), Animal and Plant Health Inspection Service, Wildlife Services for providing the funding for the study. We thank D. Baasch, S. Groepper, G. Clements, J. Williams, T. Ruby, J. Stoneman, T. Kinsell, and C. Zajac for assistance in the field. We thank L. Klimek, M. Sheets, S. Cooper, M. Cunard, and P. Magorian at DNWR and local farmers for providing study sites, assistance, and equipment. The Youth Conservation Corps at DNWR provided assistance. We thank Associate Editor Rollins for the helpful comments and review of the manuscript. Mention of companies or commercial products does not imply recommendation or endorsement by University of Nebraska-Lincoln or the USDA, nor does omission imply criticism. Product names are mentioned solely to report factually on available data and provide specific information.

\section{LITERATURE CITED}

Côté, S. D., T. P. Rooney, J. Tremblay, C. Dussault, and D. M. Waller. 2004. Ecological impacts of deer overabundance. Annual Review of Ecology, Evolution, and Systematics 35:113-147.

Craven, S. R., D. J. Decker, S. E. Hygnstrom, and W. F. Siemer. 1992. Survey use and landowner tolerance in wildlife damage management. North American Wildlife and Natural Resource Conference 57:75-88.

Craven, S. R., and S. E. Hygnstrom. 1994. Deer. Pages D25-D40 in S. E. Hygnstrom, R. M. Timm, and G. E. Larson, editors. Prevention and 
control of wildlife damage. University of Nebraska Cooperative Extension, Lincoln, USA.

DeVault, T. L., J. C. Beasley, L. A. Humberg, B. J. MacGowan, M. I. Retamosa, and O. E. Rhodes, Jr. 2007. Intrafield patterns of wildlife damage to corn and soybeans in northern Indiana. Human-Wildlife Conflicts 1:205-213.

Eldredge, J. C. 1935. The effect of injury in imitation of hail damage on the development of the corn plant. Iowa Agricultural Home Economic Experimental Station Resource Bulletin 185, Ames, USA.

Engeman, R. M., and R. T. Sterner. 2002. A comparison of potential laborsaving sampling methods for assessing large mammal damage in corn. Crop Protection 21:101-105.

Engeman, R. M., and R. T. Sugihara. 1998. Optimization of variable area transect sampling using Monte Carlo simulation. Ecology 79:1425-1434.

Gilsdorf, J. M., S. E. Hygnstrom, K. C. VerCauteren, E. E. Blankenship, and R. M. Engeman. 2004a. Propane exploders and electronic guards were ineffective at reducing deer damage in cornfields. Wildlife Society Bulletin 32:524-531.

Gilsdorf, J. M., S. E. Hygnstrom, K. C. VerCauteren, G. M. Clements, E. E. Blankenship, and R. M. Engeman. 2004b. Evaluation of a deeractivated bio-acoustic frightening device for reducing deer damage in cornfields. Wildlife Society Bulletin 32:515-523.

Hygnstrom, S. E., J. R. Hygnstrom, K. C. VerCauteren, N. S. Foster, S. B. Lembezeder, and D. J. Hafer. 1992. Effects of chronological deer damage on corn yields. Eastern Wildlife Damage Control Conference 5:65.

Lavelle, M. J., J. W. Fischer, S. E. Hygnstrom, J. J. White, A. M. Hildreth, G. E. Phillips, and K. C. VerCauteren. 2010. Response of deer to containment by a poly-mesh fence for mitigating disease outbreaks. Journal of Wildlife Management 74:1620-1625.

Littell, R. C., G. A. Milliken, W. W. Stroup, R. D. Wolfinger, and O. Schabenberger. 2006. SAS for mixed models. Second edition. SAS Institute, Cary, North Carolina, USA.

MacGowan, B. J., L. A. Humberg, J. C. Beasley, T. L. DeVault, M. I. Retamosa, and O. E. Rhodes, Jr. 2006. Corn and soybean crop depredation by wildlife. Department of Forestry and Natural Resources Publication FNR 265-W, Purdue University, West Lafayette, Indiana, USA.
McLean, R. A., W. L. Sanders, and W. W. Stroup. 1991. A unified approach to mixed linear models. The American Statistician 45:54-64.

McNew, K., and J. Curtis. 1997. Deer, ecosystem damage, and sustaining forest resources. Pages 13-20 in B. L. Gardner, editor. Deer as public goods and public nuisance: issues and policy options in Maryland. Center for Agricultural and Natural Resource Policy, College Park, Maryland, USA.

Pearce, E. A., and G. Smith. 1990. The Times Books world weather guide: updated edition. Times, New York, New York, USA.

Retamosa, M. I., L. A. Humberg, J. C. Beasley, and O. E. Rhodes, Jr. 2008. Modeling wildlife damage to crops in northern Indiana. Human-Wildlife Conflicts 2:225-239.

SAS Institute Inc. 2008. SAS/STAT ${ }^{\circledR} 9.2$ User's Guide. SAS Institute, Cary, North Carolina, USA.

Shapiro, C. A., T. A. Peterson, and A. D. Flowerday. 1986. Yield loss due to simulated hail damage on corn: a comparison of actual and predicted values. Agronomy Journal 78:585-589.

Smathers, W. M., Jr., G. R. Stratton, and D. Shipes. 1993. Landowners perceptions of crop damage from white-tailed deer in South Carolina. Eastern Wildlife Damage Control Conference 6:160-165.

U.S. Department of Agriculture. 2011. Corn, sorghum, barley, and oats: planted acreage, harvested acreage, production, yield, and farm price. $<$ http://www.ers.usda.gov/Data/FeedGrains/Table.asp?t=01>. Accessed 11 Apr 2011.

VerCauteren, K. C., and S. E. Hygnstrom. 1998. Effects of agricultural activities and hunting on home ranges of female white-tailed deer. Journal of Wildlife Management 62:280-285.

VerCauteren, K. C., M. J. Lavelle, and S. E. Hygnstrom. $2006 a$. A simulation model for determining cost-effectiveness of fences for reducing deer damage. Wildlife Society Bulletin 34:16-22.

VerCauteren, K. C., M. J. Lavelle, and S. E. Hygnstrom. 2006b. Fences and deer-damage management: a review of designs and efficacy. Wildlife Society Bulletin 34:191-200.

Vorst, J. J. 1986. Assessing hail damage to corn. NebGuide 803. University of Nebraska-Lincoln Cooperative Extension Service, Lincoln, USA.

Associate Editor: Rollins. 